DOI https://doi.org/10.30525/978-9934-26-111-4-16

\title{
ЕКОЛОГО-ФІЗІОЛОГІЧНІ ОСОБЛИВОСТІ ОДНОРІЧОК СОНЯЧНОГО ОКУНЯ (LEPOMIS GIBBOSUS (L., 1758)) В ОЗЕРАХ ПРОЕКТОВАНОГО ЕКОПАРКУ «ОСОКОРКИ»
}

\author{
Коваленко Ю. О. \\ доктор філософії, молодмий науковий співробітник \\ Інститут гідробіології Наџіональної академії наук України \\ Причепа М. В. \\ кандидат біологічних наук, науковий співробітник \\ Інститут гідробіології Національної академії наук України \\ м. Київ, Украӥна
}

Сонячний окунь - інвазивний вид, що зустрічається в озерах, струмках та невеликих річках зі значною кількістю макрофітів [10, с. 1133]. До Свропи він був завезений з Північної Америки в кінці $1800-x$ років [6, с. 195], в даний час він розширив ареал як мінімум у 28 країнах Європи та Малої Азії [7, с. 230]. В Україну с. окунь потрапив з території Німеччини (р. Дунай). Крім того, у 1970-х рр. його розводили на дослідному рибному господарстві під м. Києвом [1, с. 19-20]. Негативний вплив с. окуня на аборигену іхтіофауну вперше було описано в Іспанії та Португалії [12, с. 228] із зазначенням, що вид особливо чисельний у антропогенно-порушених водоймах [5, с. 15]. В озерах Ванкувера зростання чисельності с. окуня відобразилось на скороченні кількості корюшкових та лососевих риб. Крім того, в Канаді він сприяв зникненню 7 з 41 рідкісних видів риб $[8$, c. 14]. Для боротьби з інвазією с. окуня, іспанські річки зариблювали харчовим конкурентом - струмковою фореллю (Salmo trutta) статевозрілого віку, яка позитивно вплинула на зниження чисельності молоді с. окуня $[10$, с. 10]. 3 огляду на це, дослідження с. окуня в країнах Свропи є важливими та наразі зосереджені на вивченні його вікових, ростових та морфологічних особливостях в різних географічних регіонах $[12$, с. 228]. Стало відомо, що інтродукція с. окуня у європейські водойми призвела до формування більш видовженої форми тіла (максимальні показники середнього значення довжини голови, спинного та грудного плавців, постдорсальної відстані, висоти тіла) відносно до особин 3 материнського ареалу [2, c. 54-55]. 3 огляду на це метою досліджень було встано- 
вити еколого-фізіологічні особливості однорічок с. окуня Lepomis gibbosus L., у весняний період.

Відлов с. окуня проводився за допомогою сачка у першій-другій декаді травня 2021 р. Дослідні озера розташовані у віддаленій від антропогенного навантаження зоні міста та відрізняються за особливостями заростання та видовим складом макрофітів. Дно оз. Мартишів переважно піщане із наявністю вищих водяних рослин: Ceratophyllum demersum, Myriophyllum spicatum, Elodea canadensis. Досліджувані локації оз. Тяглого мали значні глибини та мулисте дно. Оз. В'язки характеризувалось наявністю піщаного дна і прибережного поясу вищих водяних рослин. Серед занурених рослин: Potamogeton perfoliatus, Potamogeton crispus, Elodea canadensis, Ceratophyllum demersum, Myriophyllum spicatum.

За результатами досліджень було встановлено, що найчисельнішими видами були верховодка звичайна (Alburnus alburnus), краснопірка звичайна (Scardinius erythrophthalmus), гірчак європейський (Rhodeus amarus). Плоскирка звичайна (Blicca bjoerkna), вівсянка (Leucaspius delineatus), плітка звичайна (Rutilus rutilus), лящ (Abramis brama), окунь річковий (Perca fluviatilis), с. окунь (Lepomis gibbosus), щука (Esox lucius) та іглиця пухлощока (Syngnathus abaster) траплялись із середньою частотою, а бичок-пісочник (Neogobius fluviatilis) та карась (Carassius s.p.) - зустрічались поодинокими особинами. Відомо, що с. окунь із водойм різних регіонів України відрізняється між собою за низкою пластичних та меристичних ознак. У наших дослідженнях вид з окремих озер Осокорівської заплави теж мав відмінності за низкою морфометричних показників та характеризувався наступними пластичними ознаками (Табл. 1). Варто зазначити, що вид харчується переважно ракоподібними та комахами, також він може споживати дрібних риб, ікру та рослинність $[11$, с. $1133 ; 3,23]$. Для кількісної оцінки умов існування риб використовують коефіцієнти вгодованості, що відображають наявність достатньої кількості кормових об'єктів [4, с. 56 ]. За результатами проведених досліджень було встановлено, що у весняний період найменша вгодованість за Фультоном спостерігалась у риб з оз. В'язки, в якому досліджувана вибірка мала на 34,14 \% меншу вгодованість, ніж вибірка 3 оз. Мартишів та на 23,17\% меншою, ніж у риб з оз. Тягле. Втім за Кларк коефіцієнти вгодованості не мали статистично достовірних відмінностей (Табл. 1). Також у риб із оз. В'язки та Тягле спостерігалась менша загальна маса та лінійний розмір тіла, що може вказувати на найбільш сприятливі умови для с. окуня у з оз. Мартишів. За поверхневою оцінкою, однорічки с. окуня харчувались переважно рослинною їжею, дрібними равликами та іншими організмами бентосу. 70 
Таблиця 1

Морфо-фізіологічні показники сонячного окуня $(\mathrm{M} \pm \mathbf{m}, \mathbf{n}=\mathbf{2 5})$

\begin{tabular}{|c|c|c|c|}
\hline Ознаки & о3. Мартишів & оз. Оз. В'язки & о3. Тягле \\
\hline Maca, $\Gamma$ & $1,11 \pm 0,026$ & $0,85 \pm 0,053$ & $0,63 \pm 0,08$ \\
\hline ad & $4,06 \pm 0,027$ & $3,75 \pm 0,059$ & $3,66 \pm 0,166$ \\
\hline \multicolumn{4}{|c|}{ Пластичні ознаки } \\
\hline \multicolumn{4}{|c|}{ У \% від довжини тіла } \\
\hline ao & $29,4 \pm 0,08$ & $26,87 \pm 0,26$ & $31,2 \pm 0,51$ \\
\hline $\operatorname{lm}$ & $25,33 \pm 0,08$ & $23,91 \pm 0,16$ & $23,42 \pm 0,31$ \\
\hline gh & $28,37 \pm 0,1$ & $24,83 \pm 0,20$ & $26,43 \pm 0,35$ \\
\hline ik & $8,22 \pm 0,06$ & $8,03 \pm 0,093$ & $7,34 \pm 0,2$ \\
\hline $\mathrm{fd}$ & $19,47 \pm 0,07$ & $15,13 \pm 0,15$ & $19,38 \pm 0,33$ \\
\hline $\mathrm{aq}$ & $30,77 \pm 0,08$ & $27,67 \pm 0,14$ & $26,65 \pm 0,55$ \\
\hline rd & $56,53 \pm 0,11$ & $44,15 \pm 0,18$ & $54,36 \pm 0,6$ \\
\hline ay & $3,28 \pm 0,09$ & $1,98 \pm 0,14$ & $3,6 \pm 0,096$ \\
\hline qs & $36,63 \pm 0,15$ & $28,27 \pm 0,19$ & $34,09 \pm 0,42$ \\
\hline $\mathrm{yy}_{1}$ & $15,69 \pm 0,07$ & $14,74 \pm 0,17$ & $11,22 \pm 0,33$ \\
\hline \multicolumn{4}{|c|}{ У \% від довжини голови } \\
\hline an & $23,97 \pm 0,08$ & $16,23 \pm 0,21$ & $14,85 \pm 0,39$ \\
\hline po & $41,99 \pm 0,09$ & $32,45 \pm 0,28$ & $36,68 \pm 0,44$ \\
\hline$a_{1} a_{2}$ & $22,03 \pm 0,11$ & $17,77 \pm 0,22$ & $15,01 \pm 0,40$ \\
\hline $\mathrm{k}_{1} \mathrm{l}_{1}$ & $33,32 \pm 0,1$ & $17,65 \pm 0,16$ & $29,11 \pm 0,48$ \\
\hline \multicolumn{4}{|c|}{ Коефіцієнти вгодованості } \\
\hline за Футоном & $2,68 \pm 0,051$ & $1,89 \pm 0,063$ & $2,46 \pm 0,23$ \\
\hline за Кларк & $1,68 \pm 0,032$ & $1,58 \pm 0,044$ & $1,75 \pm 0,19$ \\
\hline
\end{tabular}


Усереднені лінійні довжини однорічок с. окуня 3 озер проектованого екопарку «Осокорки» виявились більшими, ніж 3 популяції с. окуня з р. Гуадальківі (з Іспанія), (3,2 см)) [9, с. 23], проте не значно меншими, ніж з популяції цього виду з низки озер Болгарії $(4,6-5,5$ см) [12, с. 230]. За пластичними ознаками найбільше відмінностей спостерігалось за: найбільшою висотою тіла, довжиною основи анального плавця, довжиною рила (найбільша 3 оз. Мартишів), позаочною відстанню, довжиною верхньої щелепи та довжиною нижньої щелепи.

Отже, отримані результати показали, що найбільша вгодованість та лінійно-масові показники були в особин з оз. Мартишів, яке мало найбільше заростання макролітами. Встановлено, що риби 3 досліджуваних водойм відрізнялись за 5 пластичними ознаками. Отримані результати $є$ попередніми та потребують подальшого дослідження.

\section{Література:}

1. Афанасьев С. А., Гупало Е. А., Мантурова О. В. Расселение и особенности биологии солнечного окуня Lepomis gibbosus (Perciformes: Centrarchidae) в водоемах Киева. Гидробиологический журнал. 2017. Т. 53, № 1. С. 16-27.

2. Коваль С. С., Форощук В. П. Поширення та морфологічні особливості сонячного окуня Lepomis gibbosus (Linnaeus, 1758) у водоймах Луганщини. GEO\&BIO. 2020. № 19, С. 54-58.

3. Новіцький Р. О. Масштаби, спрямованість та наслідки інвазій чужорідних видів риб у дніпровські водосховища автореф. дис. ... д-ра біол. наук : 03.00.10. Київ, 2019. 41 с.

4. Єсіпова Н. Б., Федоненко О.В. Індикаторні показники екологічного стану популяцій риб. Вісник Дніпропетровського університету. Серія Біологія. Екологія. 2005. Т. 1. № 13. С. 56-60.

5. Almeida D., Almodóvar A., Nicola G.G., Elvira B. Feeding tactics and body condition of two introduced populations of pumpkinseed Lepomis gibbosus: taking advantages of human disturbances? 2009. Ecology of Freshwater Fish. Vol. 18. №1. P. 15-23.

6. Aberth J. Ecologies and Economies in Medieval and Early Modern Europe: Studies in Environmental History for Richard C. Hoffmann. Boston. 2010. P. 231.

7. Copp G. H, Fox M., 2007. Growth and life history traits of introduced pumpkinseed (Lepomis gibbosus) in Europe, and the relevance to 
invasiveness potential. In: Freshwater Bioinvaders: Profiles, Distribution, and Threats [ed. by Gherardi F.]. Springer. 2007. P. 289-306.

8. Dextrase A. J., Mandrak N. E. Impacts of alien invasive species on freshwater fauna at risk in Canada. 2006. Biological Invasions. № 8. 13-24.

9. Gutiérrez-Estrada J. C., Pulido-Calvo I., FernBndez-Delgado C. Age-structure, growth and reproduction of the introduced pumpkinseed (lepomis gibbosa, 1. 1758) in a tributary of the Guadalquivir river (southern Spain). Limnetica, 2000. № 19. P. 21-29.

10. Jordan C., Backe N., Wright M.C., Tovey C.P. Biological synopsis of pumpkinseed (Lepomis gibbosus). Can. Manuscr. Rep. Fish. Aquat. Sci. 2886: iv. 2009. 16 p.

11. Keast A., Walsh L. Daily feeding periodicities, food uptake rates, and dietary changes with hour of day in some lake fishes. J. Fish. Res. Board Can. 1968. Vol. 25. № 6. C. 1133-1144.

12. Uzunova E., Velkov B., Studenkov S., Georgieva M., Nikolova M., Pehlivanov L., Parvanov D. Growth, age and size structure of the introduced pumpkinseed (Lepomis gibbosus L.) population from small ponds along the Vit River (Bulgaria). Bulgarian Journal of Agricultural Science. 2008. Vol. 14. №2. P. 227-234.

DOI https://doi.org/10.30525/978-9934-26-111-4-17

\title{
ПЕРЕРОЗПОДІЛ СУМАРНОЇ АКТИВНОСТІ ${ }^{137} \mathrm{CS} \mathrm{У} \mathrm{ЛІСОВІЙ}$ ПІДСТИЛЦІ ТА МІНЕРАЛЬНІЙ ЧАСТИНІ ГРУНТУ СВІЖИХ ТА ВОЛОГИХ СУБОРІВ УКРАЇНСЬКОГО ПОЛІССЯ
}

\author{
Мельник В. В. \\ кандидат сільськогосподарських наук, \\ асистент кафедри екології \\ Державний університет «Житомирська політехніка» \\ м. Житомир, Украӥна
}

У лісових екосистемах лісові грунти $є$ початковою ланкою всіх біогеохімічних циклів. Найбільш поширеними грунтами в лісових екосистемах Полісся України є дерново-підзолисті, оторфовані та торф'яні. Дані грунти характеризуються низьким лісорослинним потенціалом, що обгрунтовується легким механічним складом, високою кислотністю, малим вмістом обмінних катіонів і гумусу [1, с. 35]. Такі характеристики дерново-підзолистих грунтів дозволили радіоекологам 